\title{
THE METHODS OF TEACHING AND LEARNING FIQH IN ISLAMIC BOARDING SCHOOL, ISLAMIC SCHOOL AND PUBLIC SCHOOL
}

\section{Athoillah}

Islamic Higher Education (STAI) Sebelas April Sumedang, Indonesia

Jl. Pangeran Geusan Ulun No.116, Sumedang Sel., Sumedang, West Java 45311

Email: atho63hm@gmail.com

\section{ABSTRACT}

Figh is a compulsory subject even becomes the core in education pesantren, madrasah and school, because figh will affect the real life of individual or society in worship (mahdhah) as well as in being muamalah. Teaching learning methods of fiqh in schools consists of: bandongan (wetonan) or lecture; sorogan/private; mudzakarah/musyawarah/munadzarah (discussion), tahfidz. (memorizing), tathbiq (demonstration/socio drama) and so on. Teaching learning methods in madrasah or school basically are the same as in pesantren with different terms. Teaching learning methods in pesantren are certainly the forerunner of learning methods in madrasah and school, because historically pesantren is the oldest Islamic institution in Indonesia which presence along with the arrival of Islam into the archipelago which is in Perlak, the west coast of Sumatra in the 1st century of Hijriah. The differences of teaching learning system of fiqh on three educational institutions that are characteristics of each institution. In pesantren, fiqh is taught by non-classical systems. Teaching learning is based on the holly book of fiqh (kutub turats) are not regulated in the programmed syllabus, but adhering to the chapters contained in the holly book is examined. In madrasah, figh is a separate subject from a clump of Islamic Religious Education (PAI), while at school, fiqh as an integral part of the subject of PAI. In madrasah and schools, teaching learning of figh based on the curriculum was assigned by the government as the enactment of the stages of the implementation of the curriculum in 2013 to PAI at madrasah by the Ministry of Religious from July of the academic year 2014/2015 and in schools established by Ministry of Education and Culture and academic year starting in July 2013/2014.

Keywords: Fiqh, Pesantren and Madrasah

\section{ABSTRAK}

Fikih merupakan mata pelajaran wajib babkan inti pendidikan di Pesantren, Madrasab dan Sekolah, karena fikih akan mempengarubi kehidupan nyata individu maupun kelompok masyarakat baik dalam beribadah (mahdhah) maupun bermuamalah. Metode pembelajaran fikih di pesantren meliputi: metode bandongan (wetonan) atau ceramah; sorogan/privat; 
mudzakarah/musyawarah/munadzarah (diskusi), tahfidz, (hapalan), tathbiq (demontrasi/sosio drama) dsb. Metode pembelajaran di Madrasah atau Sekolah pada dasarnya sama dengan di Pesantren dengan istilah yang berbeda. Metode pembelajaran di Pesantren dipastikan menjadi cikal bakal metode pembelajaran di madrasah dan sekolah, karena secara historis pesantren merupakan lembaga pendidikan Islam tertua di Indonesia yang kehadirannya seiring dengan datangnya Islam ke kepulauan Nusantara yakni di Perlak, Pantai Barat Sumatera pada abad ke-1 H. Perbedaan sistem pembelajaran fikih pada tiga lembaga pendidikan tersebut merupakan ciri khas masing-masing lembaga. Di Pesantren, fikih diajarkan dengan sistem non-klasikal. Pembelajaran didasarkan atas kitab Fikih klasik (kutub turats) yang tidak diatur dalam silabus yang terprogram, melainkan berpegang pada bab-bab yang tercantum dalam kitab yang dikaji. Di Madrasah, fikih merupakan mata pelajaran tersendiri dari rumpun Pendidikan Agama Islam (PAI) sedangkan di Sekolah, fikih sebagai bagian integral dari materi mata pelajaran PAI. Di Madrasah dan di Sekolah, pembelajaran fikih didasarkan pada kurikulum yang telah ditetapkan pemerintah sebagaimana ditetapkannya tahapan implementasi kurikulum 2013 untuk PAI pada Madrasab oleh Kementerian Agama mulai Juli tabun pelajaran 2014/2015 dan di Sekolah ditetapkan oleh Kementerian Penddikan dan Kebudayaan mulai Juli tahun pelajaran 2013/2014.

Keywords: Fikih, Pesantren dan Madrasah

\section{INTRODUCTION}

Fiqh (Islamic jurisprudence) is part of Islamic law which contains Abkam Syari'yah 'Amaliyah, the provisions and laws to guide pratical issues (amaliyab) on how to worship God (Allah SWT), to do daily human relationship in order to fulfil life necessity, to do relationship in the family and to govern public life to ensure peace in the society relationship (Yafi, 1994, p. 114). Because figh dominates human daily practical guidelines, therefore this knowledge discipline is often called Islamic law. In non formal and formal educational institutions such as Islamic boarding school (pesantren), Islamic school (madrasah) and public school, fiqh must be studied and even becomes the focus of teaching and learning in those educational institutions.

Pesantren is the oldest Islamic educational institution in Indonesia. The foundation of pesantren was at the same time with the coming of Islam in the Archipelago, in the West Coast of Sumatera, which according to Buya Hamka, was in the 7th centuryAD(first century of Hijra) brought by Arab traders from Gujarat, India (Suryanegara, 2009, p. 99).

The teaching and learning system in the pesantren initially used non classical system, but later it adopted classical educational system like in public school and religious school (madrasab) (Arifin, 1993, p. 3). The teaching and learning methods in pesantren becomes the pioneer of the teaching and 
learning methods in madrasah and public school. Therefore, this article tries to explain the teaching and learning process and methods of the figh subject in the education system of pesantren, madrasah and public school.

\section{Teaching and Learning Fiqh in Pondok Pesantren Definition of Pesantren and Pondok Pesantren}

Pesantren is one of the Islamic educational institutions which has existed and been developed for a long time in Indonesia along with the coming of Islam into the Archipelago. According to Dhofier, "pesantren" is derived from the word santri (Islamic boarding school student) with the additional of preposition $p^{-}$-and the suffix of -an which means the place where santri lives. Dhofier also explains that according to Prof. Jhons, the term santri is originally from Tamil, which means religious teacher, while according to C.C. Berg, the term is from the word "shastri" which in Indian language means the people who knows Hindu religious books; the word "shastri" is originally from the word "shastra" which means the holy books, religious books or books which containts knowledge (Dhofier, 1982 p. 18). Recently, this word is narrowly used for the person who studies Islamic classical books in the pesantren.

Pondok (in Arabic is "Funduk." which means sleeping room or simple motel) is a traditional Islamic education hostel occupied by santri who live under the guidance of kyai (Islamic religious teacher). Initially, pesantren does not have a hostel. The students who study under the guidance of kiayi (pesantren leader) lived in the villages or the houses of the villagers surrounding the pesantren and they only go to the pesantren when they want to study (Arifin, 1993, p. 3). Due to the moment, the pesantren has been equipped by the hostel, then it is called "pondok pesantren" (Dhofier, 182, p. 18).

In a later development, the term pesantren or pondok pesantren is written in Indonesian law with the meaning of society based Islamic religious educational institution which conducts religious education or being integrated with other types of education (Peraturan Pemerintah No. 55, 2007). Therefore, pesantren or pondok pesantren is an integral part of the national education system as non-formal educational institution under the supervision of the Ministry of Religious Affairs.

\section{The Component and Type of Pondok Pesantren}

Pondok pesantren as Islamic educational institution has various forms and activities. Generally, the similarities of pesantren can be seen from two aspects: physical and non-physical aspects. 
Physically, there are four components that are always acquired by each pesantren, as follows:

a. Kyai as the leader, educator, teacher and model,

b. Santri as student,

c. Mosque as the place to conduct education, teaching and worship,

d. Pondok as a hostel for students to live.

The non-physical component is the religious teaching delivered by using various methods which generally has similarities, that is the standardisation of the good and bad value system, which becomes the basis of the life and the development of pondok pesantren (Dhofier, 1982 p. 44).

Based on LP3ES research in Bogor West Java, physically there are five types of pondok pesantren: The first type consists of the mosque and the house of kyai. This is the simple type pesantren in which kyai uses mosque and his own house as the place to study. His students come from the area surrounding the pesantren itself. The second type consists of the mosque, the house of kyai, and the hostel (pondok) to stay for students who come from along way of the pesantren. The third type of pesantren consists of the mosque, the house of kyai and pondok by adopting the system of wetonan (bandongan), and sorogan. This third type of pondok pesantren has undertaken formal education such as madrasah.

The fourth type of pondok pesantren, other than having the third type of pondok pesantren, it has skill education such as craft, workshop, communal shop, paddy field, garden, etcetra. The fifth type is modern pondok pesantren or development pondok pesantren in which other than having the above physical types, it has also some buildings such as library, common kitchen, dining area, administration office, shops, guest house, operation rooms and others (M. Sarijo, 1980, p. 15). According to Imran Arifin (1993, p. 7), the above five types of pondok pesantren are similar with the types of pondok pesantren in Indonesia.

\section{The Teaching of Classical Books in Pondok Pesantren.}

One of the specific characteristics of the pesantren is that there is the teaching of the yellow books (classical Islamic books printed usually in a yellow paper). Dhofier argues that without the teaching of classical Islamic books, pondok pesantrenis not considered original. Therefore, the teaching of classical Islamic books (the yellow books/kitab kuning) is the specific characteristic of education and teaching in the Salafiyah (non-modern) pesantren. The main objective of teaching this classical books is to educate the prospective ulama (scholars) in order to be loyal to the traditional Islamic thought. 
The yellow books taught in pesantren can be categorised into eight groups: (1) Nabwu (grammar) and sharaf (morfology), (2) Fiqh (Islamic Jurispridence), (3) Ushul Fiqh (the Principles of Islamic Jurispridence), (4) Hadits (Muhammadan tradition), (5) Tafsir( Qur'anic exegesis), (6) Taubid (theology), (7) Tasawuf (sufism) and Islamic ethic (8) other branches of knowledge such as History and Eloquence (Balaghah). These books are taught by using sorogan or bandongan methods in Java and Madura and by using Javanese language (Dhofier, 1982 p. 15). The kyai usually not only reads and translates the books but also interprets and comments both the content and the language of the texts. In addition, the kiayi also evaluates the teaching and learning process directly by asking his students to read and explain the meaning of the texts and then the kiayi corrects the mistakes that his students make during this process.

\section{Curriculum and Figh Reference in Pesantren}

Figh is the most important compulsory subject taught in pesantrenbecause it becomes the technical guideline in worshipping Allah and in relationship with other human beings. Moreover, figh has concrete implication on individual and collective daily life such as how a person prays, does the pilgrimage, trades and slaughters the animals well. Because of this, according to Martin van Bruinessen (1995, p. 112), even though various knowledge disciplines such as Arabic language, theology and ethics are taught in the pesantren, the core subject of pesantren education is fiqh.

Curriculum in the pesantren is not standardised or not being regulated by structured syllabus, but based on the chapters of the books being studied. To know general picture of the curriculum, it can be seen from figh books being studied in the pesantren. Based on van Bruinessen's research $(1978 / 1998)$ on the curriculum of 46 pesantren (18 pesantren in East Java/EJ, 12 pesantren in Central Java/CJ, 9 pesantren in Wet Java/WJ, 3 pesantren in South Kalimantan/SK and 4 pesantren in several areas of Sumatra/S), the data shows the following results (Bruinessen, 1995, p. 115):

List of Books of Fiqhand Ushul Fiqh

\begin{tabular}{|l|c|c|c|c|c|c|c|}
\hline $\begin{array}{l}\text { Areas } \\
\text { Number of Pesantren }\end{array}$ & $\begin{array}{c}\text { S } \\
\mathbf{4}\end{array}$ & $\begin{array}{c}\text { SK } \\
\mathbf{3}\end{array}$ & $\begin{array}{c}\text { WJ } \\
\mathbf{9}\end{array}$ & CJ 12 & EJ 18 & $\begin{array}{c}\text { Tot } \\
\mathbf{4 6}\end{array}$ & $\begin{array}{c}\text { Level of } \\
\text { difficulty }\end{array}$ \\
\hline List of Fiqh Books \\
\hline Fath al-Mu'in & 2 & 1 & 7 & 6 & 16 & 32 & Aliyah/High \\
\hline I'anat al-Thalibin & 2 & 0 & 6 & 5 & 7 & 20 & \\
\hline Taqrib & 2 & 0 & 6 & 5 & 7 & 20 & Tsanawiyah/Middle \\
\hline Fath al-Qorib & 2 & 1 & 4 & 7 & 9 & 23 & High \\
\hline Kifayatul al-Akhyar & 1 & 0 & 6 & 4 & 7 & 18 & High \\
\hline Bajuri & 1 & 0 & 1 & 0 & 1 & 3 & \\
\hline Iqna' & 0 & 1 & 1 & 0 & 5 & 7 & \\
\hline
\end{tabular}




\begin{tabular}{|c|c|c|c|c|c|c|c|}
\hline $\begin{array}{c}\text { Areas } \\
\text { Number of Pesantren }\end{array}$ & $\begin{array}{l}S \\
4 \\
\end{array}$ & $\begin{array}{c}\text { SK } \\
3 \\
\end{array}$ & $\begin{array}{c}\text { WJ } \\
9\end{array}$ & CJ 12 & EJ 18 & $\begin{array}{l}\text { Tot } \\
46\end{array}$ & $\begin{array}{l}\text { Level of } \\
\text { difficulty }\end{array}$ \\
\hline Minhaj al-Thalibin & 2 & 0 & 2 & 0 & 1 & 5 & High \\
\hline Minhaj al-Thulab & 0 & 0 & 0 & 0 & 1 & 1 & \\
\hline Fath al-Wabhab & 0 & 1 & 5 & 4 & 10 & 20 & High \\
\hline Mabali & 4 & 1 & 1 & 2 & 1 & 9 & High \\
\hline Minbaj al-Qownim & 0 & 0 & 2 & 2 & 3 & 7 & \\
\hline Safinab & 1 & 0 & 6 & 7 & 7 & 21 & Middle \\
\hline Kasyifah al-Saja & 0 & 0 & 1 & 0 & 3 & 4 & \\
\hline Sullam al-Taufike & 0 & 1 & 5 & 2 & 13 & 21 & Middle \\
\hline Tabrir & 0 & 1 & 2 & 1 & 5 & 9 & High \\
\hline Riyadh al-Badi'ab & 0 & 0 & 2 & 1 & 3 & 6 & \\
\hline Sullam al-Munajat & 0 & 0 & 2 & 1 & 2 & 5 & \\
\hline Uqud al-Lujain & 0 & 0 & 1 & 1 & 2 & 4 & Middle \\
\hline Sittin/Syarah Sittin & 0 & 1 & 2 & 0 & 0 & 3 & \\
\hline Mubadzdzab & 0 & 0 & 0 & 1 & 2 & 3 & \\
\hline Bughyah al-Mustarsyidin & 0 & 0 & 1 & 0 & 2 & 3 & \\
\hline Mabadi Fikibiyyah & 0 & 0 & 1 & 2 & 5 & 8 & Middle \\
\hline Fikih Wadhib & 0 & 0 & 0 & 1 & 3 & 4 & Middle \\
\hline \multicolumn{8}{|c|}{ List of Ushul Fiqh Books } \\
\hline Al-Warqat/Syarabnya & 2 & 1 & 6 & 1 & 2 & 12 & High/Distinctive \\
\hline Luthaifal al-Isyarah & 1 & 0 & 3 & 0 & 6 & 10 & \\
\hline Jam'ul Jawami' & 1 & 0 & 6 & 1 & 2 & 10 & $\begin{array}{c}\text { Higbly } \\
\text { DistinctiveKhawash }\end{array}$ \\
\hline Luma' & 1 & 0 & 2 & 1 & 3 & 7 & High/Distinctive \\
\hline Al-Asybah Wa al-Nadair & 0 & 0 & 1 & 1 & 4 & 5 & $\begin{array}{c}\text { Highly } \\
\text { Distinctive/Khawas } \\
h\end{array}$ \\
\hline Bayan & 0 & 0 & 1 & 0 & 2 & 3 & Middle/High \\
\hline Bidayah al-Mujtabid & 0 & 0 & 2 & 0 & 0 & 2 & $\begin{array}{c}\text { Highly } \\
\text { Distinctive/Khawas } \\
h\end{array}$ \\
\hline
\end{tabular}

The above data show the list of Islamic classical books from the most popular (often being used) in the pesantren to the least popular books, not based on the level/sequence of the books being studied by the students. The level of the books also indicates the level of the book's difficulties to be studied, not the level of students' grade. The level in the pesantren is based more on the students' ability in understanding the yellow books. Therefore, to be in certain level, the students are tested on their ability to read the yellow books, especially for new students. Age criteria is not considered, so that even a young student can study in the high or higly distinctive level if he or she can understand certain yellow books in that level.

Among the most popular Syafi i figh books being studied in Salafiyah pesantren is Taqrib (which is also known asal-Mukhtashar oral-ghoyah wa alTaqrib) written by Abu Syuja'i al-Ishfahan. Initiated by the content of Taqrib, there are various syaroh (comments/explanations) and hasyiyah (notes) written 
by scholars from various schools of law such as the following books: Iqna, Kifayat al-Abyar, Fath al-Qarib, Taqrir, Tubfah al-Habib and Hasyyah. The derivative of the book Taqrib is depicted by van Bruinessen (1995: p. 119) in the following family tree of in the below chart:

\section{Chart of Taqrib Family Tree}

Taqrib = Mukbtashar (summary)

(Abu Syuja’i d. 593)
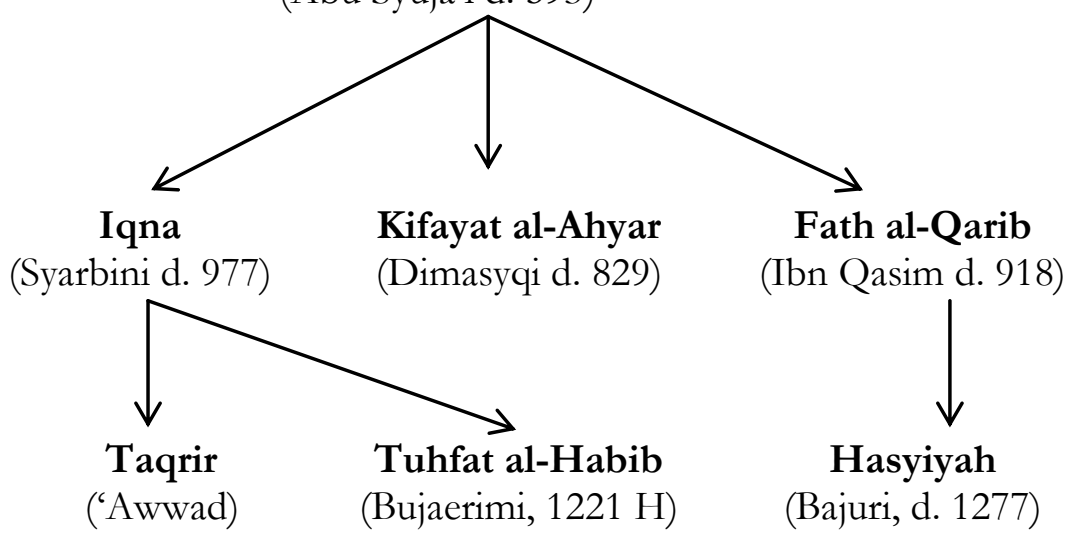

The above fiqh books, or at least one of its derivative, are still popularly being taught in pesantren. Other than Syafi'i books, as a comparison, the distinctive students in the pesantren are also taught Averrous' book, Bidayat al-mujtabid, and Sayid Sabiq's book, Fiqh Sunnah.

Tuhfatal-Habib (Bujaerimi, $1221 \mathrm{H}$ )

\section{The Methods of Teaching and Learning Fiqh Books}

Figh has been taught for a long time in various types of pesantren. Children at the basic level have been taught memorising figh books such as Durus al Fikibiyyah (for instance: with Sundanese fiqh song of ... Sakur cai ...), Parukunan Shalat. In the next level, students are being taught Safinah, Sullamu Najat, Riyad al-Badi'ah etc.by using the teaching and learning method in the pesantren.

The method being used in this teaching and learning is the method usually adopted to teach other Islamic classical books such as: Bandongan, Sorogan, Mudzakarahand "Tathbiq". These methods will be explained as follows:

a. Bandongan method. The process of teaching and learning by using this method is monologue (one way), the teacher reads the book, translates it literally pages by pages (harfiyah shafahiyah), sometimes the teacher gives explanation and comments, while the students just listen attentively while 
writing the literal meaning ("ngafsahan") and gives the symbol to the position of word in the sentence structure (i'rab). In this method, there is no dialogue between the teacher and the students (Arifin, 1993).

b. Sorogan method. In general, sorogan method is individual teaching and learning. One student sits in front of kiayi by bringing certain book. The teacher reads several lines and explains the content of the lines, then the student repeats what the teacher has explained. After this, other students would do the same, one by one. In this method, the teacher may ask the students to memorise/understand certain topic. When the students are ready, they will be asked to explain what they understand (sorog) to their teacher. In this occassion, the teacher corrects, evaluates and gives explaination if it is needed.

c. Mudzakarah method. This method is academic meeting which specifically discuss law issues. This method can be in several forms: (1) Fiqh book discussion: students usually agree to choose one of the figh books appropriate with their level to be discussed such as book of Taqrib. Technically, one of the students reads and explains certain topic and then other students respond to the explanation by explaining the structure of the sentence and law topic being discussed. (2) Deepening of the material: students discuss the materials which have been taught by the teacher in order to understand more about the materials. (3) Babs al-Masailor discussing contemporary issues: this aims to train students to solve the problem by using the available books. (4) Special guided discussion: students' discussion about actual cases guided by teacher or senior students. If the cases cannot be resolved, the teacher will help explain the cases. This method can also be done as the continuation of discussion in which the result of students' discussion is submitted to the teacher and then the teacher evaluate the students by asking various questions about the cases being discussed. Then the students answer the questions by using various argumentations and references. The most capable student who knows the issue well will be assigned by the teacher to teach other students. The time of this discussion is decided by students or being scheduled by the teacher.

d. "Tathbiq" (Enforcement) Method. It is the way to practice certain knowledge acquired by the students in order they are aware of it and practice Islamic law sincerely it. This can be manifested in the following activities forms: (1) To practice reading Islamic classical books, students (usually senior students) are asked to read the books in order to apply the knowledge about vocabulary and the grammar they studied and then the teacher corrects the students if they make any mistakes. (2) Evaluation, the teacher directly observe the application of the theory which has been 
taught such as whether or not the students pray correctly. If there is any mistake, the teacher would correct it directly just as he/she correct his/her students' daily life activities. (3) Enforcement of the pesantren order. for example, the enforcement of the obligation to pray collectively, the obligation to have night prayer, the obligation to have eclipse prayer, the obligation to do social service and the prohibition of doing any immoral acts.(4) Giving punishment in pesantren, for example at Al-Jawami Pesantren, there is Student Court which decides punishment for students who disobey the rule. For example, the students who do not participate in the collective prayer must pay a glass of rice, the students who watch film or have a date are punished by being shaven bald or being bathed with dirty water etc. This is done to raise awareness of the rule among the students (Dhofier, 1982, p. 51 and Arifin, 1993, p.111-119).

\section{Fiqh Education in Madrasah and Public School}

\section{Component of Education in Madrasah and Public School}

In educational world, there are five components which are interrelated and integrated so that they determine the achievement of educational goals. These components are: (a) Aims of education, (b) Students, (c) Educators, (d) Educational facilities and (e) Milieu (environment) (Ahmadi, 1985, p. 41). These five components are elaborated as follows:

a. The aims of education generally consist of: (1) National aims, the aims that will be achieved by all Indonesians, (2) Institutional aims, the aims that will be achieved by certain level and type of educational institution such as the aims that will be achieved by primary school, junior high school, senior high school, etc, (3) Subject aims, the aims that will be achieved by certain subject. In this context is Fiqh subject.

b. Students are the society members who try to develop themselves through educational process in certain level and type of education.

c. Educators are society members whose job is to guide, teach and/or train their students.

d. Educational facilities are all the facilities used to achieve educational aims. In the Figh subject, the facilities include the place to pray, books for each student and teaching media to explain the teaching material in a more concrete way.

e. Milieu (environment) can be in the form of objects, people, situation and event surrounding the students, either positive or negative, which can affect the students' development (Ahmadi, 1985, p. 50-51). 


\section{Teaching and Learning Fiqh in Every Level of Madrasah}

Madrasah is a formal educational institution under the Ministry of Religious Affairs which undertake general and vocational education with Islamic religion as its distinctive characteristic. This includes Raudlatul Atfal (pre-primary school level), Madrasab Ibtidaiyah (primary school level), Madrasah Tsanawiyah (secondary school level), Madrasah Aliyah (high school level) dan Madrasah Aliyah Kejuruan (vocational high school level) (Menteri Agama, 2013).

\section{a. Aims and Scopes of the Teaching and Learning Fiqh atMadrasah Ibtidaiyah (primary school)}

The Fiqh subject at Madrasab Ibtidaiyahaims at preparing the students:

1) To know and understand ways to implement Islamic law in their vertical relationship with their God (ibadab) and their horizontal life with other people (muamalah) in order to make the figh becomes a life guidance in the private and social life.

2) To implement and practice Islamic law guidelines correctly as the actualization of obedience in implementing Islamic teaching in their relationship between human and God, between human and other human beings and other creatures as well as environment (Kementerian Agama, 2013, p. 47).

The scopes of the figh subject at Madrasah Ibtidaiyah include:

1) Figh ibadah covers the ways to implement Islamic pillars correctly such as how to purify ourselves, to pray, to fast, to give alms giving and to do pilgrimage.

2) Fiqh muamalah covers the understanding about halal (lawful) and haram (unlawful) food and drink, circumcision, sacrifice, how to buy and sell and have a loan (Kementerian Agama, 2013, p. 52).

b. Aims and Scopes of the Teaching and Learning Fiqh at MadrasahTsanawiyah (secondary school level).

The teaching and learning Figh at Madrasab Tsanawiyah aims to enable students:

1) To know and understand core Islamic law in governing the provisions of how human beings relate with Allah which is discussed in figh ibadah and how human beings relate with other human beings which is discussed in fiqh muamalab;

2) To implement Islamic law correctly in worshipping Allah and in having social relationship. This experience is expected to foster obedience in implementing Islamic law, discipline, high social responsibility in personal and social life (Kementerian Agama, 2013, 


\section{p. 55).}

The scopes of the fiqh subject at MadrasabTsanawiyab include:

1) Fiqh ibadah covers the guidelines on how to purify ourselves, to do obligatory and recommended prayer and prayer in emergency situation, to kneel, to call for prayer (adzan and iqomah), to pray after the prayer (drikir), to fast, to give alms giving and to do pilgrimage, to sacrifice, to do the akikeah (to slaughter the goat after the birth of the baby), food, to care for the dead bodies and to visit the cemetery.

2) Fiqh muamalah covers the provisions of buying and selling, qiradl (giving the capital) or mudharabah (a person gives the capital to the person who would run the business and they divide the business profit based on their agreement), usury, borrowing, loan, pawning, collateral and wage.

\section{c. Aims and Scopes of the Teaching and Learning Fiqh at Madrasah Aliyah (Islamic Senior High School level)/Special Islamic Senior High School}

The teaching and learning fiqh at Madrasab Aliyah aims to enable students:

1) To know and understand the principles, rules and the procedures for the implementation of Islamic law, both in worshipping God (ibadab) and in the relationship with among human beings (mu 'amalab) in private and social life.

2) To implement the provision of Islamic law correctly as an embodiment of obedience in implementing Islamic teaching in human relationship with Allah, with the persons themselves and with other human beings as well as their environment (Kementerian Agama, 2013, p. 61).

The scopes of the fiqh subject at Madrasah Aliyah include: the principles of worshipping God (ibadab) in Islam, Islamic law and the law about alms giving and pilgrimage, their wisdom, and ways to manage them, the wisdom of sacrifice (kurban) and akikah, Islamic provision of how to care for the dead bodies, Islamic law on property, economic concept in Islam and its wisdom, Islamic law on the release and the change of property and their wisdoms, Islamic law on wakalah (giving authority to someone else to do his/her business) and sulbu (the contract agreed by the two parties to resolve the conflict or to achieve peace) and their wisdom, Islamic law on dhaman (collateral) and kafalah (collateral) and their wisdom, the usury of bank and insurance, the Islamic provision on crime (jinayat), its punishment (budud) and their wisdom, Islamic provision on establishing justice and its wisdom, 
Islamic family law, inheritance, Islamic provision on Islamic politics, the sources of Islamic law and the taklifi law (God's order and prohibition for humans to do or to avoid certain action), the basis and provisions of istimbath (producing Islamic law), the methodological principles of producing Islamic jurisprudence and their implementation (Kementerian Agama, 2013, p. 61).

The duration of teaching and learning Figh subject in each level of madrasab stated in the 2013 Curriculum is as follows: $2 \times 35$ minutes in the primary level (Madrasah Ibtidaiyah, grades 1-6) and $2 \times 40$ minutes in the secondary level (Madrasah Tsanawiyah/MTs grades 7-9), and $2 \times 45$ minutes in Madrasah Aliyah/MA and Special Islamic High School/MAK grades 10-12).

\section{d. Fiqh Education at Public School}

\section{Teaching and Learning Fiqh at Primary School and Secondary School}

The aims of teaching and learning Islamic Religious Education at primary and secondary school are to give basic ability to students about Islamic religion in order to develop their religious life so that they can be believing and pious Muslim who have noble character as individuals, society members, citizens, human beings and to prepare them to continue their education into secondary level. In Fiqh subject, they are expected to know the basic provisions of Islam to be implemented in their daily life. Just like at MI and MTs (Islamic primary and scondary school), the scope of the Fiqh subject at public primary and secondary school includes Ibadah (worshipping God), Mu'amalah (human relationship with each other), and Syariah which is directed to create harmony and balance the relationship between human and God and between human and other human as well as between humans and their environment (Depdikbud, 1994, p. 45).

Fiqh subject at primary and secondary school is different from that of at Madrasah. At public primary and secondary school, Fiqh subject becomes an integral part of Islamic Religious Education subject. This subject consists of 7 aspects: theology, ibadah, al-Qur'an, morality, mu'amalah, syari'ahand history. This subject is mandatory subject at primary and secondary school under the name of Islamic Religious Education subject (PAI). This subject was initially being taught for 90 minutes ( $2 \times 45$ minutes) per week, then in the 2013 Curriculum, it is changed into the following duration:

1) Primary school (SD) grade 1-4 is $4 \times 40$ minutes per week

2) Junior school (SMP) grade 7-9 is $3 \times 40$ minutes per week (Kementerian Pendidikan dan Kebudayaan, 2012, p. 13-16). 


\section{Teaching and Learning Fiqh at Senior High School (SLTA)}

The aim of teaching Islamic Religious Education (PAI) at Public Senior High School (SLTA, not madrasah) is to improve students' belief, understanding, appreciation and implementation of Islam so that they become believing and pious Muslim who have good characters in their private and collective live as society members and as citizens as well as "to enable students to continue their studies into a higher level" (Departemen Agama RI, 1995, p. 1). The scopes of Islamic Religious Education subject are directed to create harmony and balance the relationship between human and God and between human and other human as well as between humans and their environment.

The scopes of Islamic Religious Education at public senior high school are the same with those of at public primary and secondary school, which include seven aspects: theology, ibadah, al-Qur'an, morality, mu'amalah, syari'ah and history. The different is in their emphasis: in primary school level, the emphasis is more on the four aspects: theology, ibadah, al-Qur'an, andmorality, while injunior and senior high school another two aspects of mu'amalah and syari'ahare also taught. The aspect of history is taught in a balanced way in every level of schools (Kementerian Pendidikan dan Kebudayaan, 2012, p. 3). $43 \%$ of these 7 aspects can be categorized as Figh in the aspects of ibadah, mu'amalah and some of the aspect of syari'ah. This means that the Figh subject dominates other subjects.

The duration of teaching and learning Islamic Religious Education at public senior high school (SLTA), grades 10-12, is $3 \times 45$ per week (Kementerian Pendidikan dan Kebudayaan, 2012, p. 13-16).

The implementation of 2013 Curriculum at school and its grades is as follows:

1) July 2013 (academic year 2013/2014): grades $1,4,7$ and 10

2) July 2014 (academic year 2014/2015): grades1, 2, 4, 5, 7, 8, 10 and 11

3) July 2015 (academic year 2015/2016): grades1, 2, 3, 4, 5, 6, 7, 8, 9, 10, 11 and 12 (Kementerian Pendidikan dan Kebudayaan, 2012, p. 18).

The implementation of 2013 Curriculum on the subject of Islamic Religious Education at Madrasab began in the academic year of 2014/2015 based on the Ministry of Religious Affairs Decree No. 117/ 2014 on the Implementation of the 2013 Curriculum at Madrasah and the Ministry of Religious Affairs Rule No. 207/2014 on the enactment of the Islamic Religious Education and Arabic language curriculum at Madrasah. The implementation steps are as follows: 
1) Juli 2014 (academic year 2014/2015): grades 1, 4, 7 and 10

2) Juli 2015 (academic year 2015/2016): grades 1, 2, 4, 5, 7, 8, 10, and 11

3) Juli 2016 (academic year 2016/2017): grades 1, 2, 3, 4, 5, 6, 7, 8, 9, 10, 11 and 12

The Ministry of Education and Culture started the implementation of 2013 Curriculum on the subject of in the academic year 2013/2014 so that it would have been implemented in all levels in the academic year of 2015/2016, while the Ministry of Religious Affairs started its implementation in the academic year 2014/2015 so that it would have been implemented in all levels in the academic year of 2016/2017.

\section{Approaches and Methods of Teaching and Learning Figh at Madrasah and Public School}

Approaches and methods of teaching and learning Fiqh are as follows:

a. Habituation Approach, that is to give opportunity to students to implement Islam. To implement this approach, demonstration and other methods are used.

b. Emotional Approach, that is to arouse the students' feeling and emotion in believing, understanding and appreciating their religious teaching. To implement this approach, expository, storytelling, question and answer, demonstration, discussion and socio drama methods are used.

c. Rational Approach, that is to give role to the ratio to understand and accept the truth of their religious teaching. To implement this approach, expository, question and answer, discussion, exercise and recitation methods are used.

d. Functional Approach, that is the effort of teaching Islamic religious teaching by emphasizing its benefits for students in their daily life. To implement this approach, exercise, recitation, expository, question and answer and demonstration methods are used.

e. Experience Approach that is to give religious experience to students in cultivating Islamic values. To implement this approach, recitation, question and answer methods are used (Depdikbud, 1994, p. 46-47; Departemen Agama RI, 1994, p. 14; Departemen Agama RI, 1994, p. 3; Depag RI, 1995, p. 98-99).

In the teaching and learning Fiqh process, the teacher can choose any of the above approaches and methods based on the aims of the teaching and learning, the content which will be delivered, the existing recommendation and the availability of time in order that students can understand and implement Islamic law correctly. 


\section{CONCLUSION}

The teaching and learning in Pesantren is different from that of in the Madrasah or at Public School. In Pesantren, Figh is the core subject being taught by using non-classical system. The teaching and learning Fiqh focuses on the study of classical fiqh books and are not regulated by the structured syllabus, but based on the chapters written in those books, which are studied sequentially every pages until the end of the book chapter. The study group is not based on the age, but based on the ability of students in comprehending certain book. Generally, the level of teaching and learning Fiqh books is based on the students' comprehension of the earlier level of the books in one area of focus. For instance, students can only study the books Hasyiyah Bajuri and al-Habib (al-Bujaerimi) after they study Taqrib, Fath al-Qorib, Kkifayat alAkhyar orIqna.The study of Fiqh in Pesantren is categorised as non-formal education.

On the other hand, inMadrasahor Public School, Figh is regulated in the curriculum and its teaching and learning program has been structured. The completion of the basic level is a requirement to take further level at the secondary level and tertiary level, which is proved in the form of school certificate (Surat Tanda Tamat Belajar/STTB). Therefore, age becomes the requirement to participate in the educational institution run by the government or the society.

\section{BIBLIOGRAPHY}

Ahmadi, Abu., (1985). Metodik Khusus Pendidikan Agama Islam (MKPAI). Bandung: Armico.

Arifin, Imran., (1993). Kepemimpinan Kyai. Malang: Kalimasahada Press.

Bruinessen, Martin van., (1995). Kitab Kuning Pesantren dan Tarekat. Bandung: Mizan.

Depag RI., (1995). Kurikulum Pendidikan Dasar Berciri Khas Agama Islam GBPP MI Mata Pelajaran PAI. Jakarta: Ditjen Bimbaga Islam.

Departemen Agama RI., (1994). Pedoman Penyelenggaraan Madrasah Diniyah.

Jakarta: Proyek Pembinaan dan Bantuan kepada Ponpest.

Departemen Agama RI., (1995). Petunjuk Pelaksanaan Kurikulum/GBPP PAI

SMU Tabun 1994. Jakarta: Ditjen Bimbaga Islam.

Depdikbud., (1994). Kurikulum SLTP Petunjuk Pelaksanaan Proses Belajar

Mengajar. Jakarta: Direktorat Jendral Pendidikan Dasar dan Menengah Umum.

Dhofier, Zamakhsyari., (1982). Tradisi Pesantren. Jakarta: LP3ES.

Kementerian Agama., (2013). "Surat Keputusan Direktur Jenderal Pendidikan Islam Nomor: 2676 Tentang Kurikulum 2013 Mata 
Pelajaran Pendidikan Agama Islam Dan Bahasa Arab Di Madrasah". Jakarta: Kementerian Agama.

Kementerian Agama., (2015). "Surat Edaran Direktur Jenderal Pendidikan

Islam Kementerian Agama RI Nomor: SE/DJ.I/PP.00/143/2015 tentang Implementasi Kurikulum 2013 Pendidikan Agama Islam (PAI) pada Sekolah". Jakarta: Kementerian Agama.

Kementerian Pendidikan dan Kebudayaan., (2012). Dokumen Kurikulum 2013. Jakarta: Kementerian Pendidikan dan Kebudayaan.

Menteri Agama., (2013). "PMA No. 90 tentang Penyelenggaraan Pendidikan Madrasah, Pasal 1 ayat (2)".

Menteri Agama., (2014). "Keputusan Menteri Agama RI Nomor 117 tentang Implementasi Kurikulum 2013 di Madrasah". Jakarta: Kementerian Agama.

Menteri Agama., (2014). "Peraturan Menteri Agama RI Nomor 2017 tentang Pemberlakuan Kurikulum Pendidikan Agama Islam dan Bahasa Arab di Madrasah". Jakarta: Kementerian Agama.

Peraturan Pemerintah., (2007). No. 55 tentang Pendidikan Agama dan Keagamaan Pasal 1 ayat (4).

Sarijo, M., (1980). Sejarah Pondok Pesantren di Indonesia. Jakarta: Dharma Bakti. Suryanegara, Ahmad Mansur., (2009). Api Sejarah. Bandung: Salamadai Pustaka Semesta, Second Edition.

Yafi, Ali., (1994). Menggagas Fikih Sosial. Bandung: Mizan. 